\title{
Skill transferability, regret and mobility
}

Citation for published version (APA):

Borghans, L., \& Golsteyn, B. H. H. (2006). Skill transferability, regret and mobility. Researchcentrum voor Onderwijs en Arbeidsmarkt, Faculteit der Economische Wetenschappen. ROA Research Memoranda No. 2E https://doi.org/10.26481/umaror.200602E

Document status and date:

Published: 01/01/2006

DOI:

10.26481/umaror.200602E

Document Version:

Publisher's PDF, also known as Version of record

\section{Please check the document version of this publication:}

- A submitted manuscript is the version of the article upon submission and before peer-review. There can be important differences between the submitted version and the official published version of record.

People interested in the research are advised to contact the author for the final version of the publication, or visit the DOI to the publisher's website.

- The final author version and the galley proof are versions of the publication after peer review.

- The final published version features the final layout of the paper including the volume, issue and page numbers.

Link to publication

\footnotetext{
General rights rights.

- You may freely distribute the URL identifying the publication in the public portal. please follow below link for the End User Agreement:

www.umlib.nl/taverne-license

Take down policy

If you believe that this document breaches copyright please contact us at:

repository@maastrichtuniversity.nl

providing details and we will investigate your claim.
}

Copyright and moral rights for the publications made accessible in the public portal are retained by the authors and/or other copyright owners and it is a condition of accessing publications that users recognise and abide by the legal requirements associated with these

- Users may download and print one copy of any publication from the public portal for the purpose of private study or research.

- You may not further distribute the material or use it for any profit-making activity or commercial gain

If the publication is distributed under the terms of Article $25 \mathrm{fa}$ of the Dutch Copyright Act, indicated by the "Taverne" license above, 


\title{
Skill Transferability, Regret and Mobility
}

\author{
ROA-RM-2006/2E
}

Lex Borghans, Bart Golsteyn

Research Centre for Education and the Labour Market

Faculty of Economics and Business Administration

Maastricht University

Maastricht, February 2006 
ISBN-10: 90-5321-432-1

ISBN-13: 978-90-5321-432-9

Sec06.018.pdf 


\begin{abstract}
After graduation many students start working in sectors not related to their field of study or participate in training targeted at work in other sectors. In this paper, we look at mobility immediately after graduation from the perspective that educational choices have been made when these pupils had little experience of the actual working life in these professions. We develop a model where students accumulate partially transferable human capital but also learn about their professional preferences at the university and during the first years in the labor market. As a consequence of this newly acquired insight, these young workers might realize that working in another occupational field would better fit their preferences, although they are better equipped to work in their own field. The empirical analysis reveals that if wages are $1 \%$ lower due to lower skill transferability, the probability that a graduate who regrets his choice actually switches decreases by 2.2 percentage points, while those who switch on average take 0.3 months additional education.
\end{abstract}

Keywords: Regret, Mobility, Skill transfer, Training

JEL codes: J24, J44, J62

\title{
Acknowledgement
}

We would like to thank Arnaud Dupuy, Ben Kriechel, Edwin Leuven, Philip Marey, Derek Neal, Hessel Oosterbeek, Gerard Pfann, Catherine Ris, Wendy Smits, Rolf van der Velden, Maarten Vendrik, Bas ter Weel, seminar participants at the 2003 Human Capital Workshop at Maastricht University, the 2003 EALE conference in Seville and the 2003 Transitions in Youth conference at Madeira, the editor and an anonymous referee for valuable comments and Christina Lönnblad for editorial assistance. 



\section{Introduction}

Human capital investments are typically made in a context of large uncertainty, since students choose their education before they have any serious experience of working in a related field. Among others, Freeman (1975), Siow (1984) and Zarkin (1985) have analyzed uncertainty with respect to market wages related to educational choices. As noted by Weiss (1971), the individual will face an even larger uncertainty regarding his individual preferences for possible occupations. Consequently, many graduates entering the labor market discover that the occupational field they have chosen does not suit them. The consequences of this uncertainty on further investments in human capital have remained unexplored.

The aim of this paper is to analyze the effect of ex ante uncertainty on ex post human capital investment decisions. In our model in section 2 , students improve their insight about their occupational preferences and labor market prospects during the years they spend in education and during the time they enter the labor market. After graduation, they can choose whether and how intensely they will continue studying. At the same time, these graduates evaluate their choice of occupational field. Those who discover that another field better fits their personal preferences, and thus regret their initial choice, have an incentive to switch to this different field.

The key insight of the model is that the probability of graduates regretting their choice switching from one field of education to another will increase when their education provides them with skills that can easily be transferred to other disciplines. If skill transferability is relatively high, these graduates are expected to be able to switch fields with only modest additional investments in human capital and without large losses in wages due to under-utilization of their human capital. When graduates who can less easily transfer their skills switch, it can be expected that larger investments in additional human capital are needed and that larger wage drops will be experienced.

Section 3 describes the data with which we evaluate the empirical support for the model: a sample of 2,675 Dutch graduates from higher education, approached three years after graduation. A graduate is defined as a switcher when the field in which he continued his education differs from his original field and/or if the graduate indicates that his occupation does not match his education. $29.5 \%$ of the graduates switch. To measure regret, we make use of a survey question covering exactly our theoretical concept of regret. We 
ask the graduates: "Looking back, if you were free to choose again, would you choose the same study program?" Approximately $17 \%$ of the graduates report that they regret their choice.

In section 4 , we explain our empirical strategy. We estimate equations for the probability that a student switches after graduation, the loss of income if he switches and the additional training taken by those who switch. We use the fact that graduates who continue to study reveal latent information about the skill transferability of their original education. To measure differences in transferability, we therefore add separate dummies for 18 educational fields to each of the equations, mentioned above. In the second step we test the predictions of our model by comparing the estimates of the transferability parameters from these equations.

Consistent with the model, the empirical analysis in section 5 shows that conditional on regret, a high skill transferability increases the probability of switching from one field to another and that if graduates switch, they participate longer in education when transferability is lower. Furthermore, for those who change fields, wage losses are larger when transferability is lower. Hence, the results show that regret inflicts damage on a graduate's human capital and that this damage is reduced if skill transferability is higher. Concerning the magnitude of the damage, the results indicate that if wages are $1 \%$ lower due to lower skill transferability, the probability that a graduate who regrets his choice actually switches decreases by 2.2 percentage points, while those who do switch take on average 0.3 months additional education.

Next to the contribution to the literature about uncertainty in educational choices, our analysis gives new insights into other areas. Our paper is related to the literature about the transition from school to work. Ryan (2001) and Müller and Shavit (1998), among others, analyze the labor market entrance of young workers, characterized by high rates of job turnover, high rates of unemployment and discrepancies between job requirements and skills acquired at school, from the perspective of the gap between college and work these graduates must bridge. In this paper, we analyze the same transition period from the perspective that a pupil's image of working life differs from reality. From this perspective, educational choice is the crucial step, while only the consequences of earlier "mistakes" are revealed during the transition from school to work.

Furthermore our analysis contributes to the literature about training, since it adds 
repairing initial educational choices as a cause for training to the well-known arguments such as education-training complementarity (Heckman 2000, Brunello 2004) and depreciation of human capital (Ben-Porath 1967, Rosen 1976). This literature on human capital formation is generally concerned with choices of education levels. In our analysis, we instead focus on the choice of a discipline.

The literature on educational mismatch focuses on the returns to schooling of graduates with a higher level of education than the level needed in their jobs. Sloane, Battu, and Seaman (1999) and Dolton and Vignoles (2000), among others, show that although surplus education gives some positive return, overeducated workers earn less than adequately educated workers with a similar schooling. Groot (1996) shows that overeducated workers earn less and undereducated workers earn more than correctly allocated workers. Controlling for measurement error, Robst (1994) finds there to be no returns to excess schooling. McGuinness (2003) shows that wage gaps would still occur even if workers were perfectly matched to jobs due to disproportionate returns associated with the successful attainment of certain categories of jobs. Büchel and Mertens (2004) find that overeducation leads to lower relative wage growth. Hersch (1991) finds that overqualified workers are more likely to quit, are less satisfied with their jobs and take less training. Defining mismatch as a difference between the field of study required and actual field of study from which the individual has graduated, Heijke, Meng, and Ris (2003) find that graduates with more generic competencies are more likely to be mismatched and involved in training. The characteristic feature of these mismatch models is that workers are randomly assigned to jobs (Jovanovic 1979, Sauer 1998). This random assignment produces a mismatch because some workers lack the appropriate skills. While this is an effective assumption when investigating how workers are affected by a mismatch, this theory does not give any insight into the reasons for the mismatch. In our model, graduates decide whether they leave their initial education. Because our model is more explicit about the nature of the mismatch, it provides an important complement to the mismatch theory.

Our idea is linked with the literature on occupational mobility. However, a large part of the literature on occupational mobility assumes that workers can practically change jobs as often as they want and that they even use this opportunity to discover their career preferences. For instance, Neal (1999) and Miller (1984) find that young workers choose to switch often to find their optimal career path. Topel and Ward (1992) show that adjust- 
ments are mainly made by the group of new entrants as a trial-and-error process, while Sicherman and Galor (1990) analyze job changes that are an integral part of workers' careers. This means that a worker does not leave because he is mismatched, but because he intended to leave from the outset. Our analysis focuses on a switch to an entirely different field of occupations instead of a switch between two jobs within a field of occupations. Therefore, in our analysis, the loss of human capital due to switching becomes crucial. In some studies on job mobility, the loss of human capital has been studied more specifically. Shaw (1984) investigates mobility between sectors and finds that occupational skills are only partially transferable with occupational change. In standard wage equations, occupational experience therefore far better predicts the wage than overall experience. We find similar results for educational skills, which means that human capital accumulated through education is also field specific and that some skills are lost when switching from one field to another. Furthermore, Neal (1998), Bils (1985) and McLaughlin and Bils (2001) find that more able workers change jobs less often, because they have a higher loss of job-specific skills.

\section{The model}

Consider a pupil ${ }^{1}$ who starts to study. In his career, three periods can be distinguished. The first period comprises a constant $s_{1}$ years of full-time education. At the start of period 1, the pupil decides which field of education to attend. The educational decision is based on the maximization of expected utility of the professions he could practice after studying. ${ }^{2}$ This utility is derived from intrinsic (the extent to which he likes his job) and extrinsic (income) factors. At this point in time, the student is still uncertain about both his preferences and the income he can expect. We assume the intrinsic factors $\left(I_{k}\right)$ to depend on occupation $k$ and to be constant over time, ${ }^{3}$ and annual wage $\left(Y_{t}\right)$ to be derived from human capital. ${ }^{4}$ Wages $Y_{t}=\pi_{k} H_{t}(s)(1-\delta)$ are a combination of the amount of knowledge gathered by the student $H_{t}(s)=s^{\theta}$ (where $\theta(0 \leq \theta<1)$ reflects the decreasing marginal revenues of education), the occupation-specific return (market

\footnotetext{
${ }^{1}$ We use the term "pupil" to indicate an individual who is in secondary school, "student" to indicate a person who attends college and "graduate" to indicate that one has successfully finished college.

${ }^{2}$ For simplicity, utility can only be derived from working and not from studying.

${ }^{3}$ We assume that the pupil bases his choice on an estimation of $I_{k}$ and is not yet aware of the true value of his preferences. While his perception of his true preferences might change, his true preferences are constant.

${ }^{4}$ Individual subscripts are excluded from the model.
} 
value) of this knowledge $\left(\pi_{k}\right)$ and the time spent working $(1-\delta)$. The fraction $\delta$ of time not spent working is used for further education or training. We assume the elasticity of substitution between intrinsic and extrinsic factors to be unity. Therefore, people tend to like a profession more if they can earn a higher wage from it, and vice versa. ${ }^{5}$ The only costs of education are foregone earnings and switching between different fields of education is not possible in period 1. For simplicity, we also assume the interest rate to be 0 (future earnings are not discounted) and the wage is independent of work experience. The utility of the student/worker equals:

$$
U=\sum_{t} I_{k} Y_{t}
$$

When the individual graduates, he enters period 2. The length of period 2 is $s_{2}$ years. This length is also assumed to be constant. Unlike the pupil at the beginning of the first period who was characterized by uncertainty, due to his study and early labor market experience, the graduate knows his labor market position and whether he likes his discipline at the beginning of period 2. Therefore, the graduate can evaluate his choice of education and decide whether to stay in his original discipline (working and/or studying) or switching to a different one. If the graduate switches, skills from his initial field of education can be transferred to the other field of education. This implies that the amount of knowledge $(H)$ depends on the skill transferability, $\zeta_{k}$, which is specific for each field of study. If $\zeta_{k}=0$ switching involves a total re-start, if $\zeta_{k}$ increases, skills become more transferable. In period 2 , the graduate can choose the intensity of studying $(\delta)$. After period 2, no more studying is possible and the individual will work for $n$ years in the profession linked to the last education taken. A person retires at $T=t_{0}+s_{1}+s_{2}+n$, where $t_{0}$ is the age at which a person starts his education. The effect of human capital acquired at school is assumed to only become effective for the wage at the end of each period (when a diploma is obtained). Figure 1 and 2 show the behavior of graduates in time frames when they remain in their own discipline and switch to another, respectively.

\section{Figure 1}

Career path of the graduates who do not switch field of education

\footnotetext{
${ }^{5}$ An additive version of the model $\left(U=\sum_{t} I_{k}+Y_{t}\right)$ gives similar results.
} 


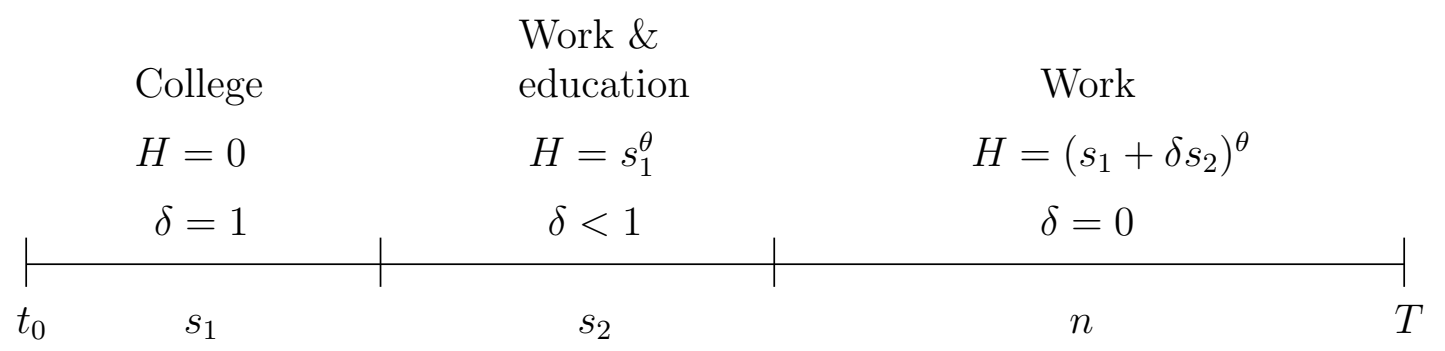

Figure 2

Career path of the graduates who switch field of education

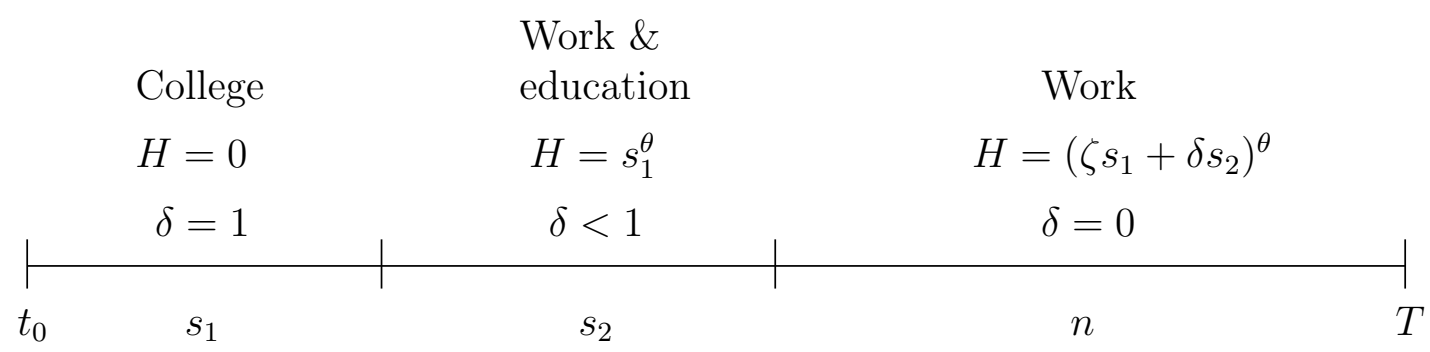

The individual's utility in a specific period can be described by:

$$
U_{t}=\left(1-\delta_{t}\right) I_{k} \pi_{k} H\left(s_{t}\right)
$$

with $\delta_{t}=1$ in period $1, \delta_{t}=\delta$ in period 2 , and $\delta_{t}=0$ in period 3 . Let us first consider what the graduate's utility will be if he stays in his educational field $k$. In this case, skills are perfectly transferable $\left(\zeta_{k}=1\right)$, since the individual has no human capital in period 1 $\left(H\left(s_{0}\right)=0\right)$ and since $\delta=1$ in period 1 and $\delta=0$ in period 3 , and utility thus becomes:

$$
U_{k}=\sum_{t=0}^{s_{1}} 0 * I_{k} \pi_{k} H\left(s_{0}\right)+\sum_{t=s_{1}}^{s_{1}+s_{2}}(1-\delta) I_{k} \pi_{k} H\left(s_{1}\right)+
$$




$$
\begin{aligned}
& +\sum_{t=s_{1}+s_{2}}^{T} 1 * I_{k} \pi_{k} H\left(s_{1}+\delta s_{2}\right) \\
& =s_{2}(1-\delta) I_{k} \pi_{k} s_{1}^{\theta}+n I_{k} \pi_{k}\left(s_{1}+\delta s_{2}\right)^{\theta} .
\end{aligned}
$$

The first part of function (3) defines the utility that can be gained in period 2, in which the individual can earn an income $s_{1}^{\theta}$ by working $(1-\delta) s_{2}$ and the second part is the income he gets in period 3 as a result of his study efforts in periods 1 and 2 .

The optimum amount the individual can study in his original discipline in period 2 can then be derived from the first-order condition for maximizing utility with respect to $\delta$ :

$$
s_{2} \delta_{k}=\left(\frac{n \theta}{s_{1}^{\theta}}\right)^{\left(\frac{1}{1-\theta}\right)}-s_{1} .
$$

This function shows that the study time in period 2 increases if the (expected) working life is longer. As opposed to this, if the income to be gained from period 1 education $\left(s_{1}^{\theta}\right)$ increases, study efforts in period 2 decrease.

Utility from the option to switch to another discipline $j$, can be derived analogously to the above. The difference is that $\zeta_{k}$ does not have to be equal to one:

$$
U_{j}=(1-\delta) s_{2} I_{k} \pi_{k} s_{1}^{\theta}+n I_{j} \pi_{j}\left(\zeta_{k} s_{1}+\delta s_{2}\right)^{\theta}
$$

Equation (5) takes into account that the amount of human capital decreases if the transferability decreases. Moreover, utility during working time in the third period is now dependent on the intrinsic valuation of the second education. ${ }^{6}$ Maximizing this function with respect to $\delta$ gives:

$$
s_{2} \delta_{j}=\left(\left(\frac{I_{j}}{I_{k}}\right)\left(\frac{\pi_{j}}{\pi_{k}}\right)\left(\frac{n \theta}{s_{1}^{\theta}}\right)\right)^{\frac{1}{1-\theta}}-\zeta_{k} s_{1} .
$$

\footnotetext{
${ }^{6}$ This is due to our assumption that graduates start working in the latest chosen profession.
} 
Function (6) shows that if the skill transferability from education $k$ in the first period to education $j$ in the second period increases, study efforts in the second period decrease. If the intrinsic value of $j$ is relatively large as compared to the intrinsic value of $k$, the study efforts in $j$ will increase. The reason for this is that the intrinsic utility from working in $k$ is lower, which reduces the opportunity costs for additional education. This is a consequence of the specification of the utility function where intrinsic value and money are not fully substitutable. With an additive utility function, this effect disappears.

By substituting the optimal duration of education in $U_{k}$ and $U_{j}$, the choice to switch or not can be derived. Utility in $j$ will be larger than or equal to utility in $k$ if:

$$
\left(\frac{I_{j}}{I_{k}}\right)\left(\frac{\pi_{j}}{\pi_{k}}\right) \geq\left(1+\frac{\theta}{1-\theta}\left(1-\zeta_{k}\right) s_{1}\left(\frac{s_{1}^{\theta}}{n \theta}\right)^{\frac{1}{1-\theta}}\right)^{1-\theta}
$$

In (7), the combination of the ratios on the left-hand side gives information about the individual's difference in ex ante and ex post perception regarding the disciplines. If the left-hand side is smaller than unity, ex post information points in the same direction as ex ante information, namely that education $k$ is the best education for the individual. If the combination of the ratios exceeds unity, however, the information after graduation points out that in retrospect, $j$ instead of $k$ would have been the better educational choice. The graduate then regrets his initial choice. The difference between ex ante and ex post utility can either stem from an overestimation of the labor market perspectives of education $k$ relative to $j$, or because the graduate simply underestimated how much he liked $j$ relative to $k$.

Second, the right-hand side of the equation exceeds unity if $\zeta$ is smaller than unity. If $\zeta$ is greater than unity, the right-hand side is smaller than unity. Hence, if the left-hand side is larger than unity and also larger than the right-hand side, a graduate who regrets his choice will switch from $k$ to $j$. A graduate who does not regret his initial education will switch if $\zeta_{k}>1 .^{7}$ Hence, conditional on the amount of regret of a graduate, the skill

\footnotetext{
${ }^{7}$ This may occur if a profession demands skills from different educations. Changing education then becomes a prerequisite for working in such a profession, not a correction of the original choice. Next to this, switching can also be explained by a consumption effect when some studies provide much direct utility but do not offer interesting job opportunities. For simplicity, we assume in our model that utility can merely be derived from an education while working. Extensions including consumption motives from education do not affect the empirical results.
} 
transferability of education $k$ determines whether a graduate will switch.

Before the start of period 1, students must choose an educational field. At that point in time, they have no perfect information about their own preferences. Denoting the expected preferences by $\hat{I}_{j}$ implies that if $\zeta_{k}$ were equal for all $k$, they would choose $k$ if $\hat{I}_{k} \pi_{k}>\hat{I}_{j} \pi_{j}$. However, if $\zeta_{k}$ 's differ between fields of study and students realize that they face uncertainty regarding their professional preferences, students close to the break-even point will tend to choose the field of study with a higher $\zeta_{k}$. Fields of study with a higher skill transferability will therefore attract more uncertain students and the frequency of regret will be higher in these fields.

\section{Data description and definitions}

The data used in the analysis are taken from the Dutch 1998 CHEERS survey. In this survey, graduates from higher vocational education and university are approached three years after their graduation in $1995 .^{8}$ Since we want to focus our analysis on regular students, we selected those aged below $35 .{ }^{9}$ 2,675 graduates remain. Their average age is 28.7 years, $56 \%$ are female, $80.5 \%$ are working with an average wage of 11.1 euros/hour.

The survey is unique for our purposes because it contains information on the (initial) chosen discipline, the discipline(s) studied in the three years after the initial education, the relation between the graduate's job and his education, the duration of the time spent studying after the original discipline and the level of regret of the original field of study.

In table 1 , the shares of respondents are reported by original educational field of study. The initial field of study is defined by the education finished in 1994/1995. The disciplines are classified by two-digit ISCED codes. As can be seen in the table, only $0.5 \%$ had followed a Life Science education, 0.1\% Manufacturing and Processing and 0.4\% a Veterinary education. These groups are excluded from the analysis. In the analyses, we use Teaching as the reference group.

-Table 1-

After graduation, respondents are able to continue their studies in the same or another field of study in the regular educational system or attend courses. In the survey, they are

\footnotetext{
${ }^{8}$ Therefore, the duration of further education is not only truncated at zero but also at three years.

${ }^{9}$ The results do not change qualitatively when all graduates are included.
} 
asked "Have you followed a course/training with the intention of substantially increasing or broadening your professional qualifications?" Therefore, courses and training for (hobby or other) non-work related purposes are not taken into account in the analysis. Both the disciplines of the regular education and the courses/training are classified with two-digit ISCED codes. A comparison of the discipline chosen after graduation with the initial field of study, determines whether the graduate switches from one field to another. Here, the implicit assumption is that a switch will be observed when there is a change in the contents of the education. Since each educational field is a combination of a number of detailed educational titles, it is possible that some individuals move between relatively different educations in the same field with no change observed, while others move between relatively similar educations that fall into different fields and a switch will be observed. We assume that, on average, graduates who move across categories experience a larger change of the contents of their education than those moving across educations within a field. $18.7 \%$ of the graduates continued their education in a different field. Besides a move from one education to another, it is possible that a graduate switches without additional education. He might start working in a job not related to his education and acquire the necessary skills on the job. Therefore, we extended the definition of switching by taking into account those graduates indicating that their job does not require the skills learned in college. The question asked is to what extent working people make use of the knowledge and skills acquired in the education finished in 1994/1995. The answer categories vary from "not at all" (1) to "to a very high extent" (5). If graduates were not at all (1) or to a small extent (2) making use of their skills, we added them to our population of switchers. $^{10}$ It can be seen from table 2 that $14.7 \%$ of the working graduates are not working in a related field. In total, the number of switchers therefore equals 29.5\%. Background information concerning switching can be found in table A1.

\section{- Table 2-}

In table A2, information is given about the origin and direction of the switchers. In our analysis, we use dummies for the education from which the graduate originates to estimate the transferability parameters. We do not take into account towards which field the graduate switches. The average distance is measured by skill transferability.

\footnotetext{
${ }^{10}$ In the robustness analysis, we investigate the effect on the results when switching is defined differently.
} 
The survey asks the length for each training expressed in months. When respondents participate in regular education, the exact beginning and ending dates are asked. ${ }^{11}$ One year of education is recoded into 12 months. Since people in general consider their formal education as more important than their training and training is often combined with work, we valued the intensity of training as half the intensity of regular education by multiplying the duration by .5. Table 3 shows that $30 \%$ of the respondents continued to study after their initial education. About half the graduates chose to study a different topic than the original discipline. Moreover, a very small amount of graduates continued to study both in their original discipline and in another discipline. In our analysis, we included these with the graduates who switched.

- Table 3-

Furthermore, in a section with questions on the field of education from which the person graduated in 1994/95, the respondents are asked: "Looking back, if you were free to choose again, would you choose the same study program?" The answers are scaled from "very probable" (1) to "not likely at all" (5). This variable is interpreted as the regret one has of studying in the original discipline. ${ }^{12}$ Table 4 shows the level of regret from the original education. Most respondents are happy with their choice, but about $17 \%$ are dissatisfied. Other surveys provided similar percentages of regret. It can be noted that the number of respondents changing disciplines increases with an increase in the level of regret. More information on the regret variable is given in the appendix. Table A3 shows that graduates with an Environmental protection or education in Journalism regret their choice most.

- Table 4-

\section{Empirical strategy}

The model shows skill transferability to be related to (1) the probability of switching (positively), (2) the duration of education if one switches (negatively) and (3) the value of

\footnotetext{
${ }^{11}$ There is no information available about the intensity of training or education in hours per week.

12 The concept of regret as defined in regret theory (introduced into economic theory by Loomes and Sugden (1982), Bell (1982) and Fishburn (1982)) fits closely to our definition. While utility directly depends on the level of regret in regret theory, utility here only depends on actual consumption and job satisfaction. In regret theory, people therefore try to avoid a situation of regret, while in our model, people just try to maximize utility.
} 
acquired human capital in another field of education (positively). Since skill transferability cannot be directly observed, we will identify the model by assuming the transferability of human capital to vary between fields of study. The empirical strategy is to estimate each of the three relationships mentioned above, using dummies for fields of study. This means that we apply a random coefficient approach where the transfer parameter in each equation depends on educational dummies plus an error term. Since the estimated parameters of these dummies reflect the same theoretical concept "transferability", this allows us to test the model by comparing the estimates of the three equations.

\subsection{Switching between fields of education}

Rewriting (7) yields

$$
s^{*}=\left(\left(\frac{I_{j}}{I_{k}}\right)\left(\frac{\pi_{j}}{\pi_{k}}\right)\right)^{\frac{1}{1-\theta}}-1-\frac{\theta}{1-\theta}\left(1-\zeta_{k}\right) s_{1}\left(\frac{s_{1}^{\theta}}{n \theta}\right)^{\frac{1}{1-\theta}},
$$

where the graduate will switch if and only if $s^{*}>0$. Assuming $\theta$ to be relatively small, equation (8) can be linearized and a straightforward expression for the decision to switch can be obtained. Because the labor market value of education is essentially reflected in a diploma and not in years of education (being a slow student is not a positive asset), we assume that the value of the initial education within the same discipline does not depend on duration. Therefore, $n \theta / s_{1}^{\theta}$ is rewritten as a constant $(\lambda){ }^{13}$ We assume the relative attractiveness of the alternative $j$ to $k$ to be a linear function of regret as measured in our survey: $\left(\frac{I_{j}}{I_{k}}\right)\left(\frac{\pi_{j}}{\pi_{k}}\right)=\gamma_{0}+\gamma_{1} *$ regret $+\epsilon$. The constants are collected in $\beta_{0}$. Because of the binary nature of the variable $s^{*}$, we write the function in logit form. Following from (8), the $\zeta$-parameters have a positive relation with switching and are conditional on the level of regret. To identify the transferability for each educational discipline, we include dummy variables for the (initial) fields of study (educ): $\zeta_{i}=\zeta_{0}+\sum_{k=2}^{k=18} \zeta_{k} * e d u c_{k}+\epsilon . \epsilon$ is assumed to have a logistic distribution. As explained above, we include interaction terms in the switching equation, separately estimating the educational dummies for graduates

\footnotetext{
${ }^{13}$ Note that this also implies that $s_{1}$ is a constant.
} 
with low levels of regret $\left(R_{0}\right.$, regret $=1$ or 2$)$ and graduates with higher levels of regret $\left(R_{1}\right) . X$ denotes the control variables gender, age and age-squared. ${ }^{14}$

$$
\begin{aligned}
s^{*} & =\beta_{0}+\beta_{1} * X+\beta_{2} * \text { regret }+R_{0} * \sum_{k=2}^{k=18} \zeta_{k}^{s_{0}} * \text { educ } \\
& + \\
\text { Switch } & =0, s_{1} * \sum_{k=2}^{k=18} \zeta_{k}^{s_{1}} * e d u c_{k}+\varepsilon \\
\text { Switch } & =1, s^{*}>0
\end{aligned}
$$

\subsection{Duration of further education}

Using the same assumptions and by linearizing, equations (4) and (6) reduce to (10) and (11) respectively, where $D_{n s}$ equals the study duration for those who do not switch and $D_{s}$ the duration for those who switch, i.e.

$$
D_{n s}=\lambda-s_{1}+\epsilon
$$

and

$$
D_{s}=\gamma_{0}+\gamma_{1} * \text { regret } * \lambda-\zeta_{k} s_{1}+\epsilon
$$

The duration function for those who do not switch reduces to a constant as shown in equation (10). The duration function for switchers also includes the amount of regret and the transfer parameter $\zeta_{k}$.

To identify the transferability of human capital, we include dummy variables for the educations. The constants $\lambda$ and $\zeta_{0}$ can be integrated with $\gamma_{0}$ leading to a new constant c. The duration function for those who switch then reduces to a linear function of a constant, the regret variable, dummies for the disciplines and an error term.

\footnotetext{
${ }^{14}$ The results are similar if the transferability parameters are not conditional on regret.
} 
Naturally, there might be other factors influencing the duration of additional education that differ between fields of study. To correct the differences in the transferability parameters for this for the non-switchers, we take the deviations of the transferability parameters in the switchers' duration function relative to the parameters in the non-switchers' duration function. This is done by estimating a system where the $\eta$ parameters, being the correction for the true $\zeta$ parameters, appear in both duration functions. We also include the regret variable in the duration function for those who do not switch to test if, as in the mathematical model, the duration for non-switchers is not affected by this variable. As in our theoretical model, we truncated the duration functions at zero. This yields

$$
\overline{D_{s}}=c+\gamma_{0} * X+\gamma_{1} * \text { regret }+\sum_{k=2}^{k=18} \eta_{k}^{d} * e d u c_{k}-\sum_{k=2}^{k=18} \zeta_{k}^{d} * e d u c_{k}+\varepsilon
$$

and

$$
\bar{D}_{n s}=c+\eta_{0} * X+\eta_{1} * \text { regret }+\sum_{k=2}^{k=18} \eta_{k} * e d u c_{k}+\varepsilon
$$

where

$$
\begin{gathered}
D_{(n) s}>0 \rightarrow D_{(n) s}=\bar{D}_{(n) s} \\
D_{(n) s}<0 \rightarrow D_{(n) s}=0 .
\end{gathered}
$$

\subsection{Wage}

Switching from one field to another will lead to a loss of human capital. The more transferable skills acquired during the first period of education are, the less the individual will suffer from this loss of human capital. Therefore, we estimate a wage equation that includes dummies for each field of study and an interaction term for each field that equals 1 only when the graduate has switched. The corresponding parameters reflect the relationship between transferability and wage, conditional on switching fields of study. In addition to the usual control variables, we include tenure. Furthermore, we included the regret variable to check whether it has an impact on the wage. We separated this variable 
for those who do not switch, $S_{0}$, and those who switch, $S_{1}$ (dummy variables). The wage function can then be written as:

$$
\begin{aligned}
\log (\text { wage }) & =\kappa_{0}+\kappa_{1} * X+\kappa_{2} * \text { tenure }+\kappa_{3} * S_{0} * \text { regret }+\kappa_{4} * S_{1} * \text { regret }+ \\
& +\sum_{k=2}^{k=18} \kappa_{k} * e d u c_{k}+\sum_{k=1}^{k=18} \zeta_{k}^{w} *\left(\text { educ } c_{k} * \text { switch }\right)+\varepsilon
\end{aligned}
$$

In our model, the wage consists of the product of human capital $(H)$ and the value of human capital $(\pi)$. Limited transferability of skills will diminish the amount of human capital. However, we measure the wage rather than the amount of human capital. Regret can be related to discrepancies between image and reality of both the intrinsic valuation and the market value of human capital in a certain field. As far as people switch field because of changes in market value, transfer losses of changing occupations will be underestimated when using a wage equation. Only when intrinsic motives are the main determinant of occupational mobility immediately after graduation, these wage effects will be an adequate measure of transferability. Since the data of the survey reveal that mobility is to a large extent driven by intrinsic aspects, we expect the wage effects to reveal the transferability of skills.

\subsection{The second step: Identifying transferability}

We expect to find that the transferability-parameters of the switch equation (9), the duration equation (12) and the wage equation (14) are all determined by the same underlying skill transferability. Allowing for scale differences and some measurement error, this means that $\zeta_{k}^{d}=\alpha_{0}^{d}+\alpha_{1}^{d} \zeta_{k}+\epsilon^{d}, \zeta_{k}^{s_{0}}=\alpha_{0}^{s_{0}}+\alpha_{1}^{s_{0}} \zeta_{k}+\epsilon^{s_{0}}, \zeta_{k}^{s_{1}}=\alpha_{0}^{s_{1}}+\alpha_{1}^{s_{1}} \zeta_{k}+\epsilon^{s_{1}}$ and $\zeta_{k}^{w}=\alpha_{0}^{w}+\alpha_{1}^{w} \zeta_{k}+\epsilon^{w}$. As a consequence, all four estimated transferability dummies must be positively related. This implies that transferability has a negative coefficient in the duration equation and a positive one in the switch equation and that our assumption holds that the loss of human capital increases, conditional on a switch, when transferability is low. To test this, we first compute the separate equations. From each equation, we find 17 transferability parameters (one for each field of study except the reference category). The relation between these parameters is tested by weighted least squares. We weigh by the 
number of graduates per educational discipline to take into account the heteroscedasticity of these estimates. Hence,

$$
\begin{gathered}
\zeta^{s_{0}}=v_{0}+v_{1} * \zeta^{d}+\epsilon, \\
\zeta^{s_{1}}=\psi_{1}+\psi_{1} * \zeta^{d}+\epsilon, \\
\zeta^{d}=\mu_{0}+\mu_{1} * \zeta^{w}+\epsilon, \\
\zeta^{s_{0}}=\omega_{0}+\omega_{1} * \zeta^{w}+\epsilon, \\
\zeta^{s_{1}}=\phi_{0}+\phi_{1} * \zeta^{w}+\epsilon, \\
\zeta^{s_{0}}=\rho_{0}+\rho_{1} * \zeta^{s_{1}}+\epsilon .
\end{gathered}
$$

To be consistent with the theoretical model, $v_{1}, \psi_{1}, \mu_{1}, \omega_{1}, \phi_{1}$ and $\rho_{1}$ must be positive. Since the estimates of the transfer parameter all contain measurement error this test of the consistency of the model does not provide any unbiased estimates of the relationship between the probability to switch (for those who regret their choice and those who do not regret their choice), the duration of additional education and wage losses. All four estimates provide a measure of transferability without any a priori scale. Since it is interesting to get an indication about the size of these effects, we also estimate the equations, each linking two measures of transferability, using a third measure as an instrument. Assuming the measurement errors to be uncorrelated, this provides unbiased estimates of the parameters.

\section{Results}

The estimation results are shown in table A4. The first column reports the estimation results from the switching equation. These results reveal a significant relationship between regret and the decision to switch to another field after graduation. Compared to Teachers, there are fields of study for which the probability to switch is significantly lower conditional on regret, but there are also fields of study with a significantly higher probability to switch. Since we measure the relative impact of transferability on the probability to switch, this measure can only be ordinally interpreted, so that 0 and 1 have no specific meaning. 
In the second and third column, the parameter estimates of the time graduates spent on further education are presented. Here, regret has no significant effect on the duration of education. In the model, this relationship resulted from the complementarity between the intrinsic and the extrinsic value of a job. As a result for graduates who like a certain job less, the utility loss of forgone income in this job is also lower. The estimation results indicate that such interaction does not exist or is at least not strong enough to be significant. In the fourth column, we report the estimates of the wage function. Tenure and age have the usual impact on wage and men earn more than women.

From the perspective of our model, it is not only crucial that regret induces switching, but also that skill transferability determines whether graduates regretting their choice actually change fields and, when they switch, how much human capital they lose and how much education they take to compensate for this loss. Since we use educational dummies as proxies for skill transferability, this implies that the relative size of these dummies has to be consistent between the different equations. In a second step, we test the relationship between these dummies by weighted (by the number of graduates per educational discipline) least squares regressions to take the heteroscedasticity of the estimations into account. Table 5 shows that the relation between the transferability parameters in the equations can be confirmed. Therefore, the data are consistent with the assumption that people lose human capital when they switch and that skill transferability has both a positive effect on switching and a negative effect on the investment in education for those who switch.

-Table 5-

In theory, the coefficients in table 5 also provide information about the relative size of the effect distinguished in the model. The coefficients are biased, however, due to the fact that both the explanatory and the dependent variable contain measurement error. To correct for this, we use IV-estimators. Assuming the error terms in each set of dummies to be independent from other sets, for each equation we use the other sets to instrument for this measurement error. Taking a linear approximation of the logistic switching function at the average of .25 for those who do not regret their choice and .39 for those who regret, we find that when graduates who switch take one additional month of training due to lower skill transferability, the probability of switching is $1.8 \%$ lower for those who do not 
regret their choice and $2.2 \%$ lower for those who regret. When wages are $1 \%$ lower after switching, graduates take on average .3 months additional training. Finally, we find some indication that students who are uncertain about their educational choice tend to more frequently choose fields of study that provide skills that can more easily be transferred to other fields.

Our model also has implications for the initial study choices. A person who is unsure about his initial choice will take the estimated skill transferability into account and strategically decide to choose a more general field of education. If the discipline was not what he expected, he will be able to switch to a different discipline without sizable costs. If uncertain persons are more likely to regret their education afterwards, those who choose a broader discipline should, on average, have a higher level of regret. We tested the relation between the transferability parameters and the mean level of regret, which indeed is significant and positive. Therefore, it can be predicted that the average amount of regret would even be higher if there were no general fields of study.

A second implication of the model is that people who do not regret their initial education, are more likely to switch if the transferability increases. We find a positive relation between the average level of switching and the transferability parameters for those who do not regret their initial choice.

\subsection{Robustness and extensions}

\subsubsection{Switching differently defined}

In our analysis, we measure a switch by monitoring the field of one's education or further education and, at the same time, the relation between the original education and the present job. We add the latter group because people can switch without additional education by starting to work in a job not related to their education and acquiring the skills on the job. In this definition, graduates who work outside their educational domain do so voluntarily. An important point is that graduates may instead also be unable to find a job related to their education. They are then involuntarily "mismatched". Our finding that switchers earn lower wages may therefore confound two effects: one due to the loss of human capital, one due to a mismatch penalty.

If we define switching as a continuation in a different field of education only, we find that if wages are $1 \%$ lower due to lower skill transferability, the probability of a graduate 
regretting his choice actually switching decreases by 5.8 percentage points, while those who switch take on average 0.4 months additional education. Comparing these estimates with the original ones, we see that the differences are small. This implies that either there are few graduates who involuntarily have a job which does not relate to their education or that these graduates react similarly to stimuli as graduates who switch education.

\subsubsection{Do low-ability graduates switch more often?}

To some it may appear that there are other reasons for switching than a high level of regret or high transferability. What if, for instance, graduates who regret their choice are typically less intelligent than those who do not regret their choice? If so, not regret but intelligence would predict switching behavior. Assuming that intelligence can be measured by wages, we checked (see table A4) if those who regret their choice receive a lower wage than graduates who do not regret their choice, both for switchers and non-switchers. We find that there is only a (significantly negative) effect for non-switchers (coefficient $=-0.063, p=0.003)$. In other words, graduates who do not switch but regret their choice of education receive lower wages than those who do not regret their choice. If intelligence were to be of importance instead of regret, we would have to find the same relationship also for switchers. The negative relation that we find for non-switchers is probably due to our strict definition of a switch, being a change from one field of study to another. It is, however, possible that a graduate switches from one discipline to another within a field of study. Then, we do not measure a switch but the graduate loses human capital because he switches.

\section{Conclusion}

The choice of discipline has an enormous impact on the satisfaction of later careers. However, students who choose their education have very limited information about what they like when they get older and what the labor market perspectives of the chosen profession are. Therefore, it is likely that some of them will regret their choice of education. To analyze the impact of regret on switching to another profession, we developed a choice model where the individual must decide after the initial education (i) whether or not to change occupations after graduation and (ii) how much to invest in education, either 
in his original discipline or in an alternative discipline. The individual maximizes his utility which depends both on wages and intrinsic motivation. From the model, it can be concluded that besides regret, skill transferability is the key determinant for his choices. If occupational mobility leads to a large loss of human capital, so transferability is low, the probability that the graduate will switch is low. However, when graduates with a low skill transferability nevertheless decide to change occupations, they will invest more in education. Using data about Dutch graduates from the CHEERS survey, we have tested our model. Consistent with our model we find that, conditional on the level of regret, higher skill transferability induces switching and reduces the wage loss and the duration of the training followed after the initial education.

\section{References}

Bell, D. (1982): "Regret in Decision Making under Uncertainty," Operations Research, 30(5), 961-981.

Ben-Porath, Y. (1967): "The Production of Human capital and the Life-Cycle of Earnings," Journal of Political Economy, 75(4), 352-365.

Bils, M. (1985): "Real Wages over the Business Cycle: Evidence from Panel Data," Journal of Political Economy, 93(4), 665-689.

Brunello, G. (2004): "On the Complementarity between Education and Training in Europe," in Education, Training and Labour Market Policies in Europe, ed. by D. Checchi, and C. Lucifora. Palgrave.

BüChel, F., And A. Mertens (2004): "Overeducation, Undereducation and the Theory of Career Mobility," Applied Economics, 36(8), 803-816.

Dolton, P., And A. Vignoles (2000): "The Incidence and Effects of Overeducation in the U.K. Graduate Labour Market," Economics of Education Review, 19(2), 179-198.

Fishburn, P. (1982): "Nontransitive Measurable Utility," Journal of Mathematical Psychology, 26(1), 31-67.

Freeman, R. (1975): "Legal Cobwebs: A Recursive Model of the Market for New Lawyers," Review of Economics and Statistics, 57(2), 171-179. 
Groot, W. (1996): "The Incidence of, and Returns to Overeducation in the U.K.," Applied Economics, 28(10), 1345-1350.

Heckman, J. (2000): "Policies to Foster Human Capital," Research in Economics, 54(1), $3-56$.

HeiJke, H., C. Meng, and C. Ris (2003): "Fitting to the Job: the Role of Generic and Vocational Competencies in Adjustment and Performance," Labour Economics, 10(2), 215-229.

Hersch, J. (1991): "Education Match and Job Match," Review of Economics and Statistics, 73(1), 140-144.

Jovanovic, B. (1979): "Job Matching and the Theory of Turnover," Journal of Political Economy, 87(5), 972-990.

Loomes, G., and R. Sugden (1982): "Regret Theory: An Alternative Theory of Rational Choice under Uncertainty," The Economic Journal, 92(368), 805-824.

McGuinness, S. (2003): "Graduate Overeducation as a Sheepskin Effect: Evidence from Northern Ireland," Applied Economics, 35, 597-608.

McLaughlin, J., and M. Bils (2001): "Interindustry Mobility and the Cyclical Upgrading of Labor," Journal of Labor Economics, 19(1), 94-135.

Miller, R. (1984): "Job Matching and Occupational Choice," Journal of Political Economy, 92(6), 1086-1120.

Müller, W., And Y. Shavit (1998): "The institutional Embeddedness of the Stratification Process, a Comparative Study of Qualifications and Occupations in Thirteen Countries," in From School to Work, ed. by Y. Shavit, and W. Müller.

NEAL, D. (1998): "The Link between Ability and Specialization, An Explanation for Observed Correlations between Wages and Mobility Rates," Journal of Human Resources, 33(1), 173-200.

(1999): "The Complexity of Job Mobility among Young Men," Journal of Labor Economics, 17(2), 237-261. 
Robst, J. (1994): "Measurement Error and the Returns to Excess Schooling," Applied Economics Letters, 1(9), 142-144.

Rosen, S. (1976): "A Theory of Life Earnings," Journal of Political Economy, 84(4), S45-S67.

Ryan, P. (2001): "The School-to-Work Transition: A Cross-National Perspective," Journal of Economic Literature, 39(1), 34-92.

SAuer, R. (1998): "Job Mobility and the Market for Lawyers," Journal of Political Economy, 106(1), 147-171.

Shaw, K. (1984): "A Formulation of the Earnings Function using the Concept of Occupational Investment," Journal of Human Resources, 19(3), 319-340.

Sicherman, N., And O. Galor (1990): "A Theory of Career Mobility," Journal of Political Economy, 98(1), 169-192.

Siow, A. (1984): "Occupational Choice Under Uncertainty," Econometrica, 52(3), 631645.

Sloane, P., H. Battu, and P. Seaman (1999): "Overeducation, Undereducation and the British Labour Market," Applied Economics, 31(11), 1437-1453.

Topel, R., And M. WARd (1992): "Job Mobility and the Careers of Young Men," Quarterly Journal of Economics, 107(2), 439-479.

WeIss, Y. (1971): "Investment in Graduate Education," American Economic Review, 61(5), 833-852.

Zarkin, G. (1985): "Occupational Choice: An Application to the Market for Public School Teachers," Quarterly Journal of Economics, 100(2), 409-446. 
Table 1

Distribution of respondents over disciplines in original education.$^{a}$

\begin{tabular}{l|c}
\hline \hline Disciplines & Percentage \\
\hline & \\
Teacher education and education science & 10.8 \\
Arts & 3.9 \\
Humanities & 4.6 \\
Social and behavioral science & 6.5 \\
Journalism and information & 2.6 \\
Business and administration & 21.0 \\
Law & 5.0 \\
Life science & 0.5 \\
Physical science & 1.9 \\
Mathematics and statistics & 0.8 \\
Computing & 3.4 \\
Engineering and engineering trades & 9.0 \\
Manufacturing and processing & 0.1 \\
Architecture and building & 3.4 \\
Agriculture and forestry & 3.0 \\
Veterinary & 0.4 \\
Health & 10.8 \\
Social services & 7.3 \\
Personal services & 3.5 \\
Transport services & 0.7 \\
Environmental protection & 0.8 \\
& \\
\hline Total & 100.0 \\
Number of graduates & 2,675 \\
\hline \hline
\end{tabular}

${ }^{a}$ Source: CHEERS, 1999 
Table 2

Usage of skills acquired by the initial education in current profession. ${ }^{a}$

\begin{tabular}{l|c}
\hline \hline Usage of skills in profession & Number of graduates \\
\hline Not working & 133 \\
Not at all & 34 \\
Very little & 340 \\
Sometimes & 846 \\
Often & 997 \\
All the time & 325 \\
& \\
\hline Total & 2,675 \\
\hline \hline
\end{tabular}

${ }^{a}$ Source: CHEERS, 1999 
Table 3

Mean duration of initial and further education and field of further education. ${ }^{a}$

\begin{tabular}{l|ccc}
\hline \hline & Response & $\begin{array}{c}\text { Initial discipline } \\
\text { (months) }\end{array}$ & $\begin{array}{c}\text { Other discipline } \\
\text { (months) }\end{array}$ \\
\hline No further education & 1,783 & 0.0 & 0.0 \\
Same field & 391 & 19.8 & 0.0 \\
Other field & 454 & 0.0 & 12.7 \\
Same and other field & 47 & 13.5 & 14.2 \\
\hline \hline
\end{tabular}

${ }^{a}$ Source: CHEERS, 1999 
Table 4

Regret of initial education and switching behavior. ${ }^{a} b$

\begin{tabular}{l|cccc}
\hline \hline Level of regret & Response & Percentage & \% switch & \% no switch \\
\hline & & & & \\
No regret & 732 & 27.4 & 21.7 & 78.3 \\
Little regret & 1,029 & 38.5 & 26.6 & 73.4 \\
Neutral & 452 & 16.9 & 32.5 & 67.5 \\
Regret & 314 & 11.7 & 37.9 & 62.1 \\
Strong regret & 148 & 5.5 & 60.8 & 39.2 \\
& & & & \\
\hline Total & 2,675 & 100.0 & 29.5 & 70.5 \\
\hline \hline
\end{tabular}

${ }^{a}$ Regret is measured by the question: Looking back, if you were free to choose again, would you choose the same study program? Answer categories range from: 1 very probable (no regret) ... 5 not likely at all (strong regret).

${ }^{b}$ Source: CHEERS, 1999 
Table 5

Correlation between transferability parameters (St. Error in parenthesis) ${ }^{a} b$

\begin{tabular}{|c|c|c|}
\hline & Coefficient & $\mathrm{R}$-squared \\
\hline $\begin{array}{l}\text { Model } 1 \text { (dependent=Switch without regret) } \\
\text { Intercept } \\
D_{s}\end{array}$ & $\begin{array}{l}0.184^{* * *} \\
(.010) \\
0.073^{* * *} \\
(0.001)\end{array}$ & 0.525 \\
\hline $\begin{array}{l}\text { Model } 2 \text { (dependent=Switch with regret) } \\
\text { Intercept } \\
D_{s}\end{array}$ & $\begin{array}{l}0.029^{* *} \\
(0.011) \\
0.056^{* * *} \\
(0.002)\end{array}$ & 0.325 \\
\hline $\begin{array}{l}\text { Model } 3 \text { (dependent=Wage) } \\
\text { Intercept } \\
\text { Duration of training }\end{array}$ & $\begin{array}{l}-0.265^{* * *} \\
(0.004) \\
0.019^{* * *} \\
(0.001)\end{array}$ & 0.301 \\
\hline $\begin{array}{l}\text { Model } 4 \text { (dependent=Wage) } \\
\text { Intercept } \\
\text { Switch without regret }\end{array}$ & $\begin{array}{l}-0.332^{* * *} \\
(0.003) \\
0.174^{* * *} \\
(0.006)\end{array}$ & 0.260 \\
\hline $\begin{array}{l}\text { Model } 5 \text { (dependent=Wage) } \\
\text { Intercept } \\
\text { Switch with regret }\end{array}$ & $\begin{array}{l}-0.319^{* * *} \\
(0.003) \\
0.183^{* * *} \\
(0.006)\end{array}$ & 0.272 \\
\hline $\begin{array}{l}\text { Model } 6 \text { (dependent=Switch without regret) } \\
\text { Intercept } \\
\text { Switch with regret }\end{array}$ & $\begin{array}{l}0.038^{* * *} \\
(0.005) \\
0.922^{* * *} \\
(0.009)\end{array}$ & 0.803 \\
\hline
\end{tabular}

$a_{\text {The estimates in this table show the relations between the transferability parameters. All relations }}$ are regressed separately by weighted least squares.

$b *=$ significant at $10 \%, * *=$ significant at $5 \%, * * *=$ significant at $1 \%$ 


\section{Appendix}

Table A1

Distribution of switching over gender and disciplines in original education. ${ }^{a}$

\begin{tabular}{l|cc}
\hline \hline Disciplines & \% No switch & \% Switch \\
\hline Male & 69.1 & 30.9 \\
Female & 71.7 & 28.3 \\
& & \\
Teachers & 70.6 & 29.4 \\
Arts & 73.1 & 26.9 \\
Humanities & 61.3 & 38.7 \\
Social sc. & 61.8 & 38.2 \\
Journalism & 68.6 & 31.4 \\
Business & 77.0 & 23.0 \\
Law & 69.6 & 30.4 \\
Life sc. & 53.8 & 46.2 \\
Physical sc. & 54.0 & 46.0 \\
Mathematics & 66.7 & 33.3 \\
Computing & 76.7 & 23.3 \\
Engineering & 58.3 & 41.7 \\
Manufacturing & 50.0 & 50.0 \\
Architecture & 68.1 & 31.9 \\
Agriculture & 65.4 & 34.6 \\
Veterinary & 81.8 & 18.2 \\
Health & 84.0 & 16.0 \\
Social & 72.8 & 27.2 \\
Personal & 61.7 & 38.3 \\
Transport & 55.0 & 45.0 \\
Environmental & 59.1 & 40.9 \\
& & \\
\hline \hline
\end{tabular}

${ }^{a}$ Source: CHEERS, 1999 
Table A2

Distribution of switchers over disciplines from which they come and to which they switch. ${ }^{a b}$

\begin{tabular}{l|cc}
\hline \hline Disciplines & $\begin{array}{c}\text { Percentage } \\
\text { from }\end{array}$ & $\begin{array}{c}\text { Percentage } \\
\text { towards }\end{array}$ \\
\hline Teacher education and education science & 10.2 & 0.0 \\
Arts & 3.2 & 2.5 \\
Humanities & 5.2 & 7.7 \\
Social and behavioral science & 8.6 & 11.7 \\
Journalism and information & 3.4 & 1.9 \\
Business and administration & 13.4 & 38.1 \\
Law & 6.4 & 5.2 \\
Life science & 0.4 & 1.1 \\
Physical science & 4.0 & 2.7 \\
Mathematics and statistics & 0.8 & 1.0 \\
Computing & 3.4 & 9.2 \\
Engineering and engineering trades & 12.2 & 5.0 \\
Manufacturing and processing & 0.0 & 0.0 \\
Architecture and building & 3.6 & 2.1 \\
Agriculture and forestry & 3.6 & 0.8 \\
Veterinary & 0.2 & 0.0 \\
Health & 4.8 & 5.7 \\
Social services & 8.4 & 2.3 \\
Personal services & 5.4 & 0.2 \\
Transport services & 1.4 & 1.5 \\
Environmental protection & 1.6 & 1.0 \\
& & \\
\hline Total & 100.0 & 100 \\
Number of switchers & 501 & 522 \\
\hline \hline
\end{tabular}

${ }^{a}$ Some people switch more than once. All fields to which they switch are reported. Therefore, the amount of switchers in their original discipline is lower than the amount of switchers in the fields to which they switch.

${ }^{b}$ Source: CHEERS, 1999 
Table A3

Distribution of regret over gender and disciplines in original education. ${ }^{a}$

\begin{tabular}{l|ccccc}
\hline \hline Disciplines & $\begin{array}{c}\text { No } \\
\text { regret }\end{array}$ & $\begin{array}{c}\text { Little } \\
\text { regret }\end{array}$ & Neutral & Regret & $\begin{array}{c}\text { Strong } \\
\text { regret }\end{array}$ \\
\hline Male & & & & & \\
Female & 27.2 & 39.3 & 16.6 & 12.6 & 4.3 \\
& 27.5 & 37.8 & 17.1 & 11.1 & 6.5 \\
Teachers & & & & & \\
Arts & 27.0 & 37.4 & 18.3 & 10.0 & 7.3 \\
Humanities & 33.7 & 40.4 & 6.7 & 13.5 & 5.8 \\
Social sc. & 21.0 & 35.5 & 21.0 & 12.9 & 9.7 \\
Journalism & 24.9 & 38.2 & 17.3 & 13.3 & 6.4 \\
Business & 18.6 & 37.1 & 18.6 & 18.6 & 7.1 \\
Law & 27.0 & 44.1 & 14.1 & 11.0 & 3.7 \\
Life sc. & 32.6 & 37.8 & 16.3 & 10.4 & 3.0 \\
Physical sc. & 38.5 & 30.8 & 15.4 & 7.7 & 7.7 \\
Mathematics & 26.0 & 36.0 & 26.0 & 8.0 & 4.0 \\
Computing & 23.8 & 33.3 & 23.8 & 4.8 & 14.3 \\
Engineering & 38.9 & 33.3 & 14.4 & 11.1 & 2.2 \\
Manufacturing & 27.5 & 37.5 & 18.3 & 12.9 & 3.8 \\
Architecture & 100 & & & & \\
Agriculture & 24.2 & 42.9 & 17.6 & 12.1 & 3.3 \\
Veterinary & 30.9 & 33.3 & 19.8 & 11.1 & 4.9 \\
Health & 36.4 & 36.4 & 18.2 & 9.1 & \\
Social & 29.9 & 33.7 & 19.1 & 11.5 & 5.9 \\
Personal & 26.7 & 39.0 & 16.9 & 11.3 & 6.2 \\
Transport & 20.2 & 41.5 & 14.9 & 12.8 & 10.6 \\
Environmental & 25.0 & 25.0 & 25.0 & 20.0 & 5.0 \\
& 9.1 & 36.4 & 18.2 & 18.2 & 18.2 \\
\hline \hline & & & & & \\
\hline
\end{tabular}

${ }^{a}$ Source: CHEERS, 1999 
Table A4

Results of Wage, Switch and Duration equations (St. Error in parenthesis).

\begin{tabular}{|c|c|c|c|c|}
\hline Variables & Switch & $D_{s}$ & $D_{n s}$ & Wage \\
\hline Intercept & $\begin{array}{l}-6.243 \\
(8.595)\end{array}$ & $\begin{array}{l}77.529 \\
(117.426)\end{array}$ & $\begin{array}{l}-22.269 \\
(172.321)\end{array}$ & $\begin{array}{l}-5.833^{*} \\
(3.279)\end{array}$ \\
\hline Regret & $\begin{array}{l}0.393^{* * *} \\
(0.064)\end{array}$ & $\begin{array}{l}0.533 \\
(0.611)\end{array}$ & $\begin{array}{l}0.093 \\
(0.875)\end{array}$ & \\
\hline Regret*switch & & & & $\begin{array}{l}0.028 \\
(0.027)\end{array}$ \\
\hline Regret*no switch & & & & $\begin{array}{l}-0.063^{* * *} \\
(0.021)\end{array}$ \\
\hline Male & $\begin{array}{l}0.127 \\
(0.105)\end{array}$ & $\begin{array}{l}0.356 \\
(1.596)\end{array}$ & $\begin{array}{l}0.196 \\
(1.965)\end{array}$ & $\begin{array}{l}0.075^{*} \\
(0.045)\end{array}$ \\
\hline Tenure & & & & $\begin{array}{l}0.002^{* *} \\
(0.001)\end{array}$ \\
\hline Age & $\begin{array}{l}0.379 \\
(0.591)\end{array}$ & $\begin{array}{l}-3.751 \\
(7.949)\end{array}$ & $\begin{array}{l}3.809 \\
(12.024)\end{array}$ & $\begin{array}{l}0.518^{* *} \\
(0.225)\end{array}$ \\
\hline Agesq & $\begin{array}{l}-0.008 \\
(0.010)\end{array}$ & $\begin{array}{l}0.063 \\
(0.134)\end{array}$ & $\begin{array}{l}-0.062 \\
(0.207)\end{array}$ & $\begin{array}{l}-0.009^{* *} \\
(0.004)\end{array}$ \\
\hline Teachers & Ref. & Ref. $(\zeta)$ & Ref. $(\eta)$ & Ref. \\
\hline Arts & & $\begin{array}{l}-7.737 \\
(6.245)\end{array}$ & $\begin{array}{l}-8.760^{*} \\
(5.324)\end{array}$ & $\begin{array}{l}-0.312^{* * *} \\
(0.115)\end{array}$ \\
\hline Humanities & & $\begin{array}{l}6.340 \\
(6.813)\end{array}$ & $\begin{array}{l}1.809 \\
(6.012)\end{array}$ & $\begin{array}{l}-0.069 \\
(0.123)\end{array}$ \\
\hline Social sc. & & $\begin{array}{l}-1.742 \\
(6.846)\end{array}$ & $\begin{array}{l}-2.856 \\
(6.200)\end{array}$ & $\begin{array}{l}0.245^{* *} \\
(0.112)\end{array}$ \\
\hline Journalism & & $\begin{array}{l}-0.087 \\
(9.514)\end{array}$ & $\begin{array}{l}-6.161 \\
(8.074)\end{array}$ & $\begin{array}{l}0.174 \\
(0.155)\end{array}$ \\
\hline Business & & $\begin{array}{l}-8.614 \\
(5.639)\end{array}$ & $\begin{array}{l}-11.862^{* *} \\
(4.863)\end{array}$ & $\begin{array}{l}0.255^{* * *} \\
(0.081)\end{array}$ \\
\hline Law & & $\begin{array}{l}-0.046 \\
(6.433)\end{array}$ & $\begin{array}{l}-6.539 \\
(5.369)\end{array}$ & $\begin{array}{l}0.362^{* * *} \\
(0.123)\end{array}$ \\
\hline Physical sc. & & $\begin{array}{l}-2.374 \\
(8.203)\end{array}$ & $\begin{array}{l}-1.597 \\
(6.691)\end{array}$ & $\begin{array}{l}0.221 \\
(0.243)\end{array}$ \\
\hline Mathematics & & $\begin{array}{l}-13.909 \\
(17.733)\end{array}$ & $\begin{array}{l}-9.376 \\
(15.285)\end{array}$ & $\begin{array}{l}0.638 \\
(0.392)\end{array}$ \\
\hline Computing & & $\begin{array}{l}0.174 \\
(9.559)\end{array}$ & $\begin{array}{l}-7.178 \\
(7.192)\end{array}$ & $\begin{array}{l}0.448^{* * *} \\
(0.160)\end{array}$ \\
\hline Engineering & & $\begin{array}{l}-0.439 \\
(6.732)\end{array}$ & $\begin{array}{l}-7.922 \\
(5.693)\end{array}$ & $\begin{array}{l}0.264^{* *} \\
(0.113)\end{array}$ \\
\hline Architecture & & $\begin{array}{l}-7.243 \\
(8.363)\end{array}$ & $\begin{array}{l}-12.208^{*} \\
(6.838)\end{array}$ & $\begin{array}{l}0.127 \\
(0.139)\end{array}$ \\
\hline
\end{tabular}


Table A4 (continued)

\begin{tabular}{|c|c|c|c|c|}
\hline Variables & Switch & $D_{s}$ & $D_{n s}$ & Wage \\
\hline Agriculture & & $\begin{array}{l}-0.584 \\
(10.001)\end{array}$ & $\begin{array}{l}-9.637 \\
(8.050)\end{array}$ & $\begin{array}{l}0.037 \\
(0.140)\end{array}$ \\
\hline Health & & $\begin{array}{l}-5.653 \\
(6.348)\end{array}$ & $\begin{array}{l}-10.311^{* *} \\
(4.963)\end{array}$ & $\begin{array}{l}0.281^{* * * *} \\
(0.087)\end{array}$ \\
\hline Social & & $\begin{array}{l}-2.042 \\
(6.917)\end{array}$ & $\begin{array}{l}-8.568 \\
(5.882)\end{array}$ & $\begin{array}{l}0.076 \\
(0.101)\end{array}$ \\
\hline Personal & & $\begin{array}{l}5.095 \\
(9.793)\end{array}$ & $\begin{array}{l}-4.435 \\
(8.853)\end{array}$ & $\begin{array}{l}0.220 \\
(0.162)\end{array}$ \\
\hline Transport & & $\begin{array}{l}-5.418 \\
(23.023)\end{array}$ & $\begin{array}{l}-8.568 \\
(21.320)\end{array}$ & $\begin{array}{l}0.018 \\
(0.405)\end{array}$ \\
\hline Environment & & $\begin{array}{l}-1.539 \\
(47.211)\end{array}$ & $\begin{array}{l}0.561 \\
(47.395)\end{array}$ & $\begin{array}{l}0.478 \\
(0.405)\end{array}$ \\
\hline Switch*Teachers & & & & $\begin{array}{l}-0.297^{* *} \\
(0.140)\end{array}$ \\
\hline Switch*Arts & & & & $\begin{array}{l}0.218 \\
(0.288)\end{array}$ \\
\hline Switch*Humanities & & & & $\begin{array}{l}-0.210 \\
(0.189)\end{array}$ \\
\hline Switch*Social sc. & & & & $\begin{array}{l}-0.320^{*} \\
(0.167)\end{array}$ \\
\hline Switch*Journalism & & & & $\begin{array}{l}-0.384 \\
(0.254)\end{array}$ \\
\hline Switch*Business & & & & $\begin{array}{l}-0.457^{* * *} \\
(0.125)\end{array}$ \\
\hline Switch*Law & & & & $\begin{array}{l}-0.115 \\
(0.208)\end{array}$ \\
\hline Switch*Physical sc. & & & & $\begin{array}{l}-0.024 \\
(0.320)\end{array}$ \\
\hline Switch*Mathematics & & & & $\begin{array}{l}-0.661 \\
(0.515)\end{array}$ \\
\hline Switch*Computing & & & & $\begin{array}{l}-0.206 \\
(0.275)\end{array}$ \\
\hline Switch*Engineering & & & & $\begin{array}{l}-0.292^{*} \\
(0.149)\end{array}$ \\
\hline Switch*Architecture & & & & $\begin{array}{l}-0.143 \\
(0.251)\end{array}$ \\
\hline Switch*Agriculture & & & & $\begin{array}{l}-0.239 \\
(0.227)\end{array}$ \\
\hline Switch*Health & & & & $\begin{array}{l}-0.425^{* *} \\
(0.181)\end{array}$ \\
\hline Switch*Social & & & & $\begin{array}{l}-0.148 \\
(0.183)\end{array}$ \\
\hline
\end{tabular}


Table A4 (continued)

\begin{tabular}{|c|c|c|c|}
\hline Variables & Switch & $D_{s} \quad D_{n s}$ & Wage \\
\hline Switch*Personal & & & $\begin{array}{l}-0.453^{*} \\
(0.236)\end{array}$ \\
\hline Switch*Transport & & & $\begin{array}{l}0.058 \\
(0.658)\end{array}$ \\
\hline Switch*Environment & & & $\begin{array}{l}-1.156^{*} \\
(0.512)\end{array}$ \\
\hline$R_{0} * \operatorname{Arts}$ & $\begin{array}{l}-0.153 \\
(0.328)\end{array}$ & & \\
\hline$R_{0} *$ Humanities & $\begin{array}{l}0.288 \\
(0.307)\end{array}$ & & \\
\hline$R_{0} *$ Social sc. & $\begin{array}{l}0.584^{* *} \\
(0.247)\end{array}$ & & \\
\hline$R_{0} *$ Journalism & $\begin{array}{l}0.441 \\
(0.387)\end{array}$ & & \\
\hline$R_{0}{ }^{*}$ Business & $\begin{array}{l}-0.405^{* *} \\
(0.195)\end{array}$ & & \\
\hline$R_{0} *$ Law & $\begin{array}{l}0.151 \\
(0.278)\end{array}$ & & \\
\hline$R_{0}{ }^{*}$ Physical sc. & $\begin{array}{l}0.774^{*} \\
(0.409)\end{array}$ & & \\
\hline$R_{0} *$ Mathematics & $\begin{array}{l}0.045 \\
(0.803)\end{array}$ & & \\
\hline$R_{0}{ }^{*}$ Computing & $\begin{array}{l}-0.253 \\
(0.357)\end{array}$ & & \\
\hline$R_{0} *$ Engineering & $\begin{array}{l}0.474^{* *} \\
(0.229)\end{array}$ & & \\
\hline$R_{0} *$ Architecture & $\begin{array}{l}0.056 \\
(0.323)\end{array}$ & & \\
\hline$R_{0} *$ Agriculture & $\begin{array}{l}0.214 \\
(0.348)\end{array}$ & & \\
\hline$R_{0} *$ Health & $\begin{array}{l}-0.762^{* * *} \\
(0.264)\end{array}$ & & \\
\hline$R_{0} *$ Social & $\begin{array}{l}-0.062 \\
(0.258)\end{array}$ & & \\
\hline$R_{0} *$ Personal & $\begin{array}{l}0.368 \\
(0.314)\end{array}$ & & \\
\hline$R_{0}{ }^{*}$ Transport & $\begin{array}{l}1.071 \\
(0.781)\end{array}$ & & \\
\hline$R_{0}{ }^{*}$ Environment & $\begin{array}{l}1.039 \\
(0.691)\end{array}$ & & \\
\hline$R_{1} *$ Arts & $\begin{array}{l}0.206 \\
(0.440)\end{array}$ & & \\
\hline
\end{tabular}


Table A4 (continued)

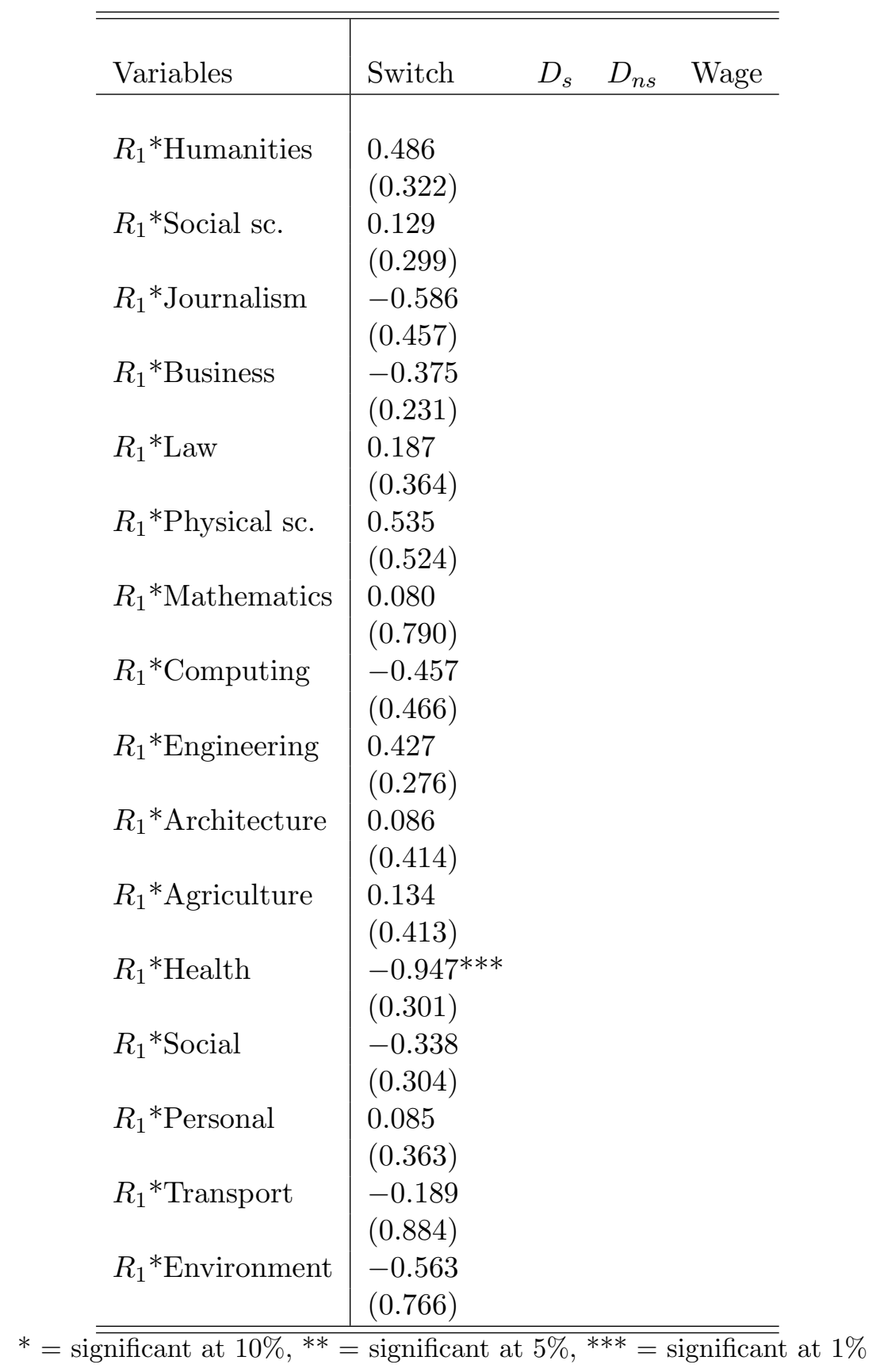

$D_{s}$ is the duration of education (in months) when a graduate switches, $D_{n s}$ is the duration of education when a graduate remains in his own field, wages are logarithms of the wage, $R_{0}$ is no regret $(1,2)$ and $R_{1}$ is regret $(3,4,5)$. 